\title{
A Wayfarer in a Land of the Free: American Sufism in the Age of DIY Religiosity
}

\author{
Nailil Muna Yusak \\ Doshisha University \\ Email: ewp1310@mail3.doshisha.ac.jp
}

\begin{abstract}
This paper observes theological shift towards a personalized spirituality of Muslim religiosity in America. In the face of global resurgence of Islamic movement and its ambitious call towards purification, personalized form of Islam is strongly criticized to be deviant and a mere practice of heresy. Islamic mysticism or commonly known as Sufism gained more popularity in modern America for its stress on God's mercy over exclusive legalism in understanding cosmic law and the divine consequences. Over the year, it has proven its catalytic role for a more peaceful interreligious understanding on account to reflexivity and cosmopolitan consciousness. Drawing from a recent scholarship by Ulrich Beck on individualized religion, this paper explores; process of individualization of religion in forming modern American religious experience and the socio-cultural relevance of Sufism in shaping contemporary religious relation of Islam in America. Data utilized in this research draws upon interviews and observational fieldworks in the East Coast America.
\end{abstract}

Keywords: American Islam, Individualization of Religion, Sufism, Islamic Mysticism.

\begin{abstract}
Abstrak
Ditengah kuatnya gerakan Islam transnasional yang mengarusutamakan pemurnian ajaran Islam, praktek keberagamaan berdasarkan penghayatan individu seringkali dikecam sebagai sebuah praktik sesat belaka. Berlawanan dengan kekhawatiran bahwa Islam yang reflektif membawa menyimpangan terhadap kemurnian ajaran Islam, artikel ini mengamati adanya kecenderungan pergeseran teologis terhadap spiritualisme refleksif di kalangan umat Muslim di Amerika dalam corak Sufisme. Sufisme di Amerika semakin mendapat tempat di tengah carut-marut modernitas Amerika karena menitikberatkan pada kasih ilahi ketimbang legalisme eksklusif dalam pemaknaan hukum dan konsekuensinya. Dengan menggunakan teori individualisasi agama Ulrich Beck, artikel ini mengupas: proses individualisasi agama dalam pembentukan pengalaman beragama umat Muslim di Amerika dan relevansi Sufisme dalam pembentukan corak keberagamaan masyarakat Amerika. Data yang digunakan dalam artikel ini berupa wawancara dan observasi lapangan yang diperoleh dari serangkaian penelitian lapangan pada komunitas Muslim di pesisir timur Amerika.
\end{abstract}

Kata Kunci: American Islam, Individualization of Religion, Sufism, Islamic Mysticism. 


\section{Background}

One of the most common misconceptions in the sociological study of religion is the perception that religion is a monolithic bloc. The study of Islam receives no exception and with this regards, Muslim religiosity appears to be a unidimensional construct (El-Menouar 2014). A Muslim, for example to the mainstream Western media, will almost always fall into a binary opposition as either practicing or nonpracticing; pro or against Sharia. This paper criticizes this long held misconstruction and provides an insider's perspective of the highly pluralistic and complex Muslim religiosity in the 21st century America.

The term religiosity itself is a complex concept and has invited many disagreements. A rationale that best explains it would be the rising interest of the terminology across disciplines. However, religiosity can be broadly understood as an individual's conviction, devotion, and veneration towards a divinity (Gallagher and Tierney 2013). Olivier Roy (2004) stresses more on the aspect of one's religious experience defining religiosity as how believers experience and formulate their relationship to religion. Gallagher and Tierney further add that in general, discussion on religiosity can either take a unidimensional or multidimensional perspective. The first approach considers the term to be synonymous with the idea of piety; religiousness; or devoutness and "... can also be used to denote an extreme view and over dedication to religious rituals and traditions". Early research on religiosity in this sense focuses highly on intensity - mostly measured by religious attendance. This method is undeniably inappropriate when applied in Islamic context because a Muslim's relationship to God can be direct and personal since intermediary agent is unnecessary as expressed in the Quran 2:186 "And when my slaves ask you (O Muhammad) concerning me, then (answer them), I am indeed near". It was also narrated from Abu Hurayrah that the Prophet said: "Our Lord descends every night to the lowest heaven when the lastthird of the night remains, and He says, "Who will call Me that I might answer him, who will ask of Me that I might give him, who will ask My forgiveness, that I might forgive him" (as narrated by al-Bukhaari, Kitaab al-Tawheed, 6940; Muslim, Salaat alMusaafireen, 1262). Given this perspective, a Muslim's religious attendance doesn't necessarily coincide with his level of religiosity.

The other approach gained more popularity since the 1960's is the multidimensional approach. To date, a significant number of research has been dedicated to explore this approach e.g. Alport and Ross (1967); and recently ElMenouar (2014). Multidimensionality in religiosity is wide ranged from belief, ritual, experience, knowledge, to orthopraxis. Arguing that these rich facets of religiosity deserve an in-depth discussion, the rest of this subsection discusses multidimensionality of religiosity. To serve the purpose of this study, this paper 
limits its focus on three basic forms religiosity i.e. extrinsic, intrinsic, and quest religiosity. Allport and Ross (1967) categorize personal religiosity into two broad classifications: intrinsic and extrinsic. Perhaps the following contrast best describes Allport and Ross' basic religiosity: Extrinsically oriented individuals are considered to use their religion to serve themselves and receive external motivations such as social contacts and sense of security. Intrinsically oriented individuals live their religion by having their religious belief guide them as well as by having an internal urge to serve the divine. Batson and Ventis (1982) proposed the third facet of religiosity i.e. quest religiosity. This form of personal religiosity allows an individual to question existentialism and the meaning of life. Quest religiosity places the self as the self-directing force in one's religious experience. Olivier Roy (2004) stresses the same notion stressing that the self, and hence the individual, is at the core of the contemporary religiosity. Quest religiosity is highly associated with flexibility in translating the meaning of religion. Although quest religiosity may sound liberating at one point, an individual who is on quest religiosity may depart from or resulted in a religious distress because of the endless flexibility it offers. Anyone observing the current trend in religiosity discourse would agree that intrinsic as well as quest religiosity are relatively harder to observe as it concerns with intangible aspect such as personal religious experience and sense of transcendence and hence, the lack of study of Muslim religiosity. However, arguing that studies on Muslim intrinsic and quest religiosity do not get enough attention it deserves, this paper explores the rising influence of Islamic mysticism or commonly known as Sufism in the formation of modern religious experience in America. For the purpose of this paper, the term Sufism and Islamic mysticism will not receive etymological elaboration and is used interchangeably in reference to the mystical experience of Muslim religiosity.

There is no exact report on American Sufi membership, but it is enough to conclude that its influence in American Muslim religiosity rises in the past decades (Hermansen 2000). Scholarly consensus recognizing Sufism as an intrinsic form of Islam raises the question of Muslim integration and social participation in American society. To answer this perennial doubt, this paper is organized as follows: First, drawing from a recent scholarship by Ulrich Beck, process of individualization of religion in the formation of modern religious experience in America will be discussed. Second, discussion on individualization's impact in interreligious relation in multicultural America will follow. This paper further highlights socio-cultural relevance of Sufism in the formation of American Islam reflexive identity and the global response towards Sufism in shaping contemporary religious relation of Islam in America. Finally, data utilized in this paper draws upon interviews from local imams, Muslim chaplains, community members and leaders of several Islamic centers as well as observational field data from several mosques 
and Islamic centers in East Coast America. This method is implemented to present an in-depth exploration of intrinsic and quest religiosity aspects of Muslims in America. Some limitation regarding sampling needs to be noted in this paper. This paper contends that the crisis of religious authority affect most to educated young Muslim in the modern day Islam as this segment are inseparable from the cyber culture also exposed more to (mis)information and therefore the most vulnerable. For this reason, sample is focused but not limited to young Muslim in the age range of 20-25 years old.

\section{Rethinking Faith in the Individualization Framework}

According to Ulrich Beck's individualization of religion thesis, discussion of individualization should never be in isolation from secularization. Secularization theory seems to suggest that modernization and religion correlated in inverse relationship. Beck's religious individualization thesis takes a different assumption: that with increasing modernization, religion does not disappear but change in appearance. Beckc (2010) proposes that while the first modernity is marked by shift from agricultural to industrial society, second modernity is marked by the shift from industrial to reflexive network or information society. Together with Barbara Adam, Ulrich beck (2005) summarizes the paradigm shift in understanding modern society in her renowned work The Risk Society and Beyond: Critical Issues for Social Theory.

Table 1. Class Society versus Risk Society

\begin{tabular}{lll}
\hline & \multicolumn{1}{c}{ Class Society } & \multicolumn{1}{c}{ Risk Society } \\
\hline - Basic social & - Collectivization & - Individualization \\
organizing principle & (into families, status & plus reflexivity \\
- Form of inequality & group, etc.) plus & - Social risk position \\
- Core contentious & tradition & - Distribution of \\
$\begin{array}{l}\text { questions of justice } \\
\text { and fairness focus }\end{array}$ & $\begin{array}{l}\text { - Social class position } \\
\text { - Distribution of }\end{array}$ & 'bads' (risks) \\
on: & goods (wealth) & - Paradigmatically as: \\
- Experienced & & Fear \\
personally & - Paradigmatically as: & - Potentially as: \\
- Experienced & Hunger & Elimination of risk \\
collectively & - Potentially as: Class & \\
& consciousness & \\
\hline
\end{tabular}


In arriving at this notion, Beck argues that secularization in second modernity does not mean the demise of religion and faith but instead the development and massive dissemination of religiosity that is based in individualization (Beck 2010). While the popular response to individualization was to perceive this process as liberating in a sense that it breaks down clanship, tribalism, religious feudalism and other constraint of industrial society, for Beck individualization only led individuals to the turbulence of world risk society characterized by reliance on one's own resourcefulness to develop a personal support network (Beck, Giddens, and Lash 1994). From the psychosocial perspective, frustration and sense of uncertainty accompanying the era of world risk society is long predicted. Since the First World War, our modern society has been increasingly marked by frustration due to lack of certainty. Frustrating events in the Muslim worlds expand further back before the 9/11 from the dissolution of the Ottoman Empire in 1924 - as Muslim community thereby lost its major religious authority and political representative to the Arab springs in 2010 followed by series of protests, uprisings and armed rebellions that follows.

A number of empirical studies show the emergence of individualized forms of Muslim religiosity worldwide i.e. a religiosity based on individual decisions rather than an institutionalized authority or as Beck puts it: the reflexive religiosity. Beck further argues that "... Muslims gradually distance themselves from religious authorities and organizations and turning to a new spirituality characterized by a process of searching, selecting, and combining that is carried out under the aegis of individual faith" (Beck 2010). Roy (2004) seconds this opinion arguing that there is similarities between contemporary Christianity and Islam as religion is expressed through an inward looking community of believers, often local, not an established institution. Knowledge of the truth is achieved through personal faith, not through years of theological learning, not through obedience to religious scholars and clerics.

Given that there is no centralized religious institution (cf. Christian church) bearing the ultimate task to define the correct belief of Islam, Beck's thesis seems to have very little impact on Muslim religiosity. But this could only be the case when Muslim religiosity is interpreted within the structure of Christian or Western concept. A caveat must be entered here that traditionally, Islamic religious authority is represented by ulama (religious experts). For centuries, with their 
extensive theological knowledge and mastery in understanding the Qur'an and hadist (prophetic tradition), ulema hold de facto hegemony to issue fatwas (religious decrees) and dominate the interpretation of Islamic laws. However in the information age of second modernity, particularly after the decline of Islamic teaching institutions, ulama's authority were deprived and slowly replaced by university graduates or even lay interpreters who are skillful at disseminating their religious knowledge through posters, leaflets, podcasts, e-newsletters and online lectures. With the emergence of new literate audiences produced by print and media technologies, fragmentation of authority led the Muslim world dispersed with little to no visibility, struggling with confusion and deviation to identify direction and destination. Zareena Grewal (2014) in her ethnographic studies on global crisis of authority elaborates that "... in the absence of the final prophet, the early Muslim community had to replace its source of divine communication with a rational infrastructure linking their educated guesses about what God wanted ... both in the Quran and the moral example of Muhammad's life [hadith]". One recurring question is: who then owns the authority to speak for Islam today? On the one hand, with a broad market of Islamic knowledge on fingertips, Islamic voices multiple drastically and on the other hand, since fatwa of ulama is not legally binding and has no exertive force thus can only be taken voluntarily, reconstruction on what it means to be a Muslim in second modernity rest more on individual decision. Olivier Roy (in Cesari 2009) explains that this authority shift is also observable in Islamic countries as Muslim start to quest which Islam is 'the true Islam'.

According to Pew Research Center (2017), about half of Americans (49\%) think at least "some" U.S. Muslims are anti-American. Although Americans views toward Muslims (as well as several of the other groups) are now warmer than they were a few years ago, for American Muslims particularly after 9/11 and the political crisis aftermath, explaining what Islam really is and isn't to the general public has become personal responsibility at the bus stop, cashier queues, and over lunch breaks. To date, eighteen years after the $9 / 11$, the aftermath effect of the events continues to ripple across the globe. Oliver Roy (2004) captures post 9/11 sentiments in a deliberative way: in times of political crisis such as the $9 / 11$, ordinary Muslim feels compelled to explain what it means to be Muslim (by an opinion poll, a neighbor, a news anchorman or spontaneously because Muslim 
anticipate the question) ... this task falls on the shoulders of every Muslim, rather than on legitimate religious authorities, simply because, as we shall see, there are so few or no established Muslim authorities in the West. It is save to argue now that post 9/11 has been very challenging for American Muslim even at individual level since to publicly state a self-identity has now become a civic duty of [American] Muslim (Roy 2004). It is important to mention here that this recognition of a personal duty comes with a potential of a great distress to an extent that Muslims could be vulnerable to strict doctrines insisting on personal responsibility such as social and political jihadism even though it used to be understood as fard kifaya (collective duty) of the ummah. This task of representation and being the spokesperson of Islam fall on the shoulder of every Muslim. Quite logically, this sudden shift towards individualized obligation jeopardizes young Muslim's selfidentity and invites a research of what it means to be a Muslim in 21st century America.

\section{The Triumph of the Self in the Second Modernity}

It is suffice to say at this point that sudden recognition of personal responsibility and the dismantling of religious institution in the second modernity gives any individual an independent decision making, endless horizons of religious options, and the custom of self account for consequences (Beck 2010). The condition of contemporary mosque life in the US reflect broad and widely disputed definitions of interpretive authority and religious leadership, and as a result, American mosque communities are often deeply divided on the question of who should lead their mosque (Grewal 2014). Hence, the rise of quest religiosity explained. The phenomenon of mosque-surfing (sometimes referred as barakah surfing) as well as unmosqued young Muslim generation mirrors this tendency. In recent years, an observable number of second generation Muslims in America no longer attends the same mosque as their parents.

In Central Jersey where field data is drawn, for example, it is getting more common that local Muslim community consists of "old people mosques and young people mosques". A personal interview with several Islamic community members in New Jersey area explains that similar tendency happens across the US. Ahmed Eid, the second generation American Muslim and The Blog contributor for The Huffington Post, explains: "[my friends] didn't necessarily have any bad 
experiences at their mosques but it just didn't feel like a relevant part of their daily lives, and others had found their spiritual edification through community activism outside the walls of the mosque." (Eid 2017). My interview with a Muslim chaplain at one of the universities in New Jersey reveals that more Muslim students are detaching themselves from their parent's Islam, enjoying a more flexible and relatable guidance as they quest. Some do it trough voluntary participation in a different religious circle as their parents while others opt for on campus dorm-life for the sake of complete detachment from family religious intervention. He agrees that frustration and confusion are observed in young Muslim students to an extent that one may consider himself spiritually Muslim, and then finds it important to stress, which is 'different from his parent's Islam'. Observing this tendency, this paper argues that even though Mosque general attendance is on the decline, a spiritual form American Islam observable among young Muslim students as more mindfulness/contemplative programs are incorporated under the service of university chaplaincies such as guided sufi meditation programs offered in the university of Redlands - California and Naropa University - Colorado and a dance meditation by the renowned Dunya McPherson in the Oregon State University.

The abovementioned contention is coherent with Pew Research Center's 2017 survey of U.S. Muslims: “ ... while the majority of U.S. Muslims are satisfied with mosques in their area, just a quarter $(27 \%)$ say the mosque is central to their spiritual life. By contrast, seven-in-ten (69\%) say they pursue their spiritual life primarily outside the mosque". The rising spiritual Islam in America is evident from the increasing volume of Sufi-themed publications, international recognition of American Sufi-oriented intellectuals (e.g. Hamza Yusuf, Omid Safi and Umar Farooq Abdullah), as well as popularity of spiritual-oriented halaqa or gatherings e.g. Hamza Yusufs Reviving the Islamic spirit (RIS) and extensive rihla or retreat journey to exotic Islamic sites e.g. Umar Farooq Abdullah's The Sacred Caravan and the Zawiyah retreat program. It is stated by both scholars of mysticism and by mystics themselves that Western Sufis are known for their personal choice to contribute to the psychological aspect personally by being therapist; institutionally, by sponsoring events and conferences and forming organizations for Sufi psychology (Malik and Hinnells 2006). Marcia Hermansen in her study on Literary Productions of Western Sufi Movements (Malik and Hinnells 2006) observes that the clientele of American Sufi movement who are spiritual seekers 
naturally take a strong interest in contemporary psychological approaches to personal growth, especially those of humanistic and transpersonal psychology. In their own personalized psychological experience of Sufi-oriented religiosity, American youth understands Rumi's poetry in their own vocabulary and able to relate to Al-Ghazali's message in the American soil. Unfortunately, there is no specific demographical record on whether majority of American Muslim has turned into Islamic mysticism or Sufism in the age of DIY religiosity but its growing significance in shaping American religious landscape without a doubt deserves more study.

\section{The (Quasi) Sufi Way: A Reflexive Response in a World Risk Society}

This paper embraces the understanding of Sufism in a broad sense. Generally speaking, Sufism can be understood as an individualized form of Islam which has spread through major sectors of the Islamic world. It is essentially a mystical form of Islam emphasizing the relationship between the individual and God (Ferguson 1996). Sufis can be categorized into an individual Sufis who are not affiliated to certain Sufi orders (tareqa) and those affiliated in Sufi order. Both channel a resounding affirmation to spiritual Islam resting on asceticism over popular tendency to reduce the religious experience into mere legalistic practices. It is worth noting here that some scholars view Sufism as an alternative, or to some extent an opposition, to ritualism, literalism, and dry scholasticism (Christmann 2008). With asceticism lies at the heart of its origin, Chrismann adds, Sufism is a conceptualization of what orthodox Islam was not: high spirited, liberal, and genuine. It is thus reasonable to argue here that Sufism induces inner spirituality into Islamic practices as the religion strongly stresses on orthopraxy or a correct conduct as reflected in the five pillars of Islam i.e. faith declaration, daily prayers, charity, fasting and pilgrimage to the holy land.

The present argument in this paper lies on the examination of individual Sufis experience. Further to my previous arguments, the scholarly consensus recognizing Sufism as an intrinsic form of Islam raises the question of Muslim integration and social participation in American society. Contrary to this pervasive concern that Sufism might draw American Muslims into religious exclusivism, Sufism gained popularity for its stress on God's universal message of love and mercy over exclusive legalism in understanding cosmic law and the divine consequences. 
Politician and cleric Rafic Zakarian (in Ferguson 1996) explains the growth of Sufism worldwide as follow: with the decline of [the Abbasid Caliphate], people turned to in greater number to the Sufis, men of God, who taught love and compassion as the way to spiritual salvation. The Sufis fulfilled the need of the times by their stress on purity and piety and a relaxed attitude to form and ritual.

Over the year, Sufism has slowly proven its catalytic role for a more peaceful interreligious understanding on account to its ascetic spirituality (riyada) and cosmopolitan consciousness in America. Earlier research on Western Sufi movement suggest that scholarly attention to Sufi movement in the West has been limited by perception that such movements were cults, New Age Movements, etc (Hermansen 2006). Later in the development of American Sufism, two basic categorizations of American Sufism was introduced by Marcia Hermansen (1998) i.e. the perennial and the hybrid movement. The perennial here refers to the idea that that there is a universal, eternal truth that underlies all religion while the hybrid refers to those movements which identify more closely with an Islamic source and content. Whether a Sufi leans to one movement or the other is not the focus of this paper. Rather, this paper aims to discover that at the grassroots level, young American Muslim enjoys being at a free floating Sufi-oriented Muslim without any strict commitment to either categorization. A third categorization that this paper tries to introduce is the quasi or soft Sufism. Based on an extensive four weeks observation on several Muslim religious communities in East Coast America, quasi Sufism among young Muslim American is characterized by reflexivity and cosmopolitan consciousness. These characteristics will be further elaborated in the following section.

In the framework of individualized religion, Ulrich Beck (2010) defines reflexivity as one's personal engagement in constructing their own lives and their social and biographical identities. In this sense, an individual is forced to create a biographical narrative of their own and continuously revise their definition of themselves. As an individual takes the path of Sufism, with a guidance of a murshid (teacher) or without, a Muslim will dedicate himself to exert himself in spiritual struggle and ascetic disciple in knowing the self, God, and his religion through meditation, zikr (remembrance of God) as well as glorification of the exemplary character of the prophet in the sacred form of devotional singing known as ilahis. This notion of a long life seeker is very common in the narrative of Sufi-oriented 
Muslim as reflected in Grewal's ethnographic studies on American studenttraveller and their transnational models of sacred learning as a mean to navigate their Muslim identity (and religious authority) post 9/11 event. As Grewal (2014) puts it: " ... American student-travelers and their peers and teachers in the Middle East tend to imagine themselves as seekers partaking in a free-floating pedagogical ritual (the rihla)." In many other literatures, Sufi-oriented Muslims are often referred to as a wayfarer denoting someone who travels on (their own) foot.

Malik (2006) emphasizes that later generation of mystics have always been trying to classify the scattered ideas of their ancestors, probing their past and exploring the present. Rationalizing their own experience enables American Muslim to (re)examine his relationship with his native traditions and customs in order to create a meaningful religious practice - an approach to Islamic practices which is commonly frowned upon due to the charge of heresy. Not surprisingly, Sufi-oriented educational organization in America is built upon a curriculum that integrates Islam with Western philosophy. The students at Zaytuna College, the first liberal arts Islamic seminary in California for example, studies both American canon and classical books on Islamic tradition in their efforts to prepare American Muslim who are grounded in Islamic scholarly tradition and conversant with the cultural currents and critical ideas shaping modern society. In their website, heavily influenced by Sufi scholars from Imam Abu Hamid Al-Ghazali, Rabia Al-Adawiyya to Imam Ibn Al-Athaillah Al-Iskandari, Zaytuna College states their school mission as:

"to educate students to become morally, intellectually, and spiritually accomplished persons who, having been rigorously trained in the Islamic and Western scholarly traditions, are ready to interact with and shape modern society by the light of principles that transcend it, being motivated constantly by the intention of finding the extent of human wisdom".

In reference to my earlier argument, celebration of religious reflexivity is made possible within Sufi practices as Sufism stresses on inner religiosity over what constitutes as the 'right' manifestation of Islam. In addition to its emphasis on the careful observation the soul and inner experience, Sufism also gains popularity in American soil for its ability to intensify these sacralized them through cosmopolitan consciousness. The idea of cosmopolitanism in this paper borrows Ulrich Beck's (2010) defining cosmopolitanism as the erosion of clear boundaries separating 
markets, states, civilizations, cultures and not least the life worlds of different peoples and religions, as well as the resulting worldwide situation of an involuntary confrontation with the alien others. Cosmopolitanization, Beck adds, grow a worldwide trend towards the rediscovery of national identity. In the framework of reflexive modernity, it would be utterly mistaken to equate cosmopolitanization with globalization. Beck offers a clear cut distinction between the two suggesting that wile globalization is something that happens 'out there', cosmopolitanism happens within, in the realms of the nation, the local, and even one's own biography and identity. In a simple term, cosmopolitanism abolishes the duality of global and local, national and international, and to merge them with one another in a new conjoined form.

Drawing from the classical Sufi thought of Imam Al-Ghazali, Ferguson (1996) explained the relationship between Sufism, individualization, and cosmopolitan consciousness: "The complete mystic way includes both intellectual belief and practical activity. The latter consists in getting rid of the obstacles in the self and in stripping off its base characteristics and vicious morals, so that the heart may attain freedom from what is not God and to constant recollection of Him." However, this paper contends, the search for true self-understanding of reality is a universal existential quest as long as humanity endures. Historically, when Sufism was still considered as Eastern spirituality in the West, it was the universal wisdom Sufism (e.g. freedom, peace and harmony) that promotes its growth in America. Some of the earliest American Sufi orders, Pir Vilayat Khan for example, were very open to non-Muslim as well as female membership as the order focuses on the universal worship through musical chants and meditation practices (Hermansen 2000). David Damrel (in Malik and Hinnells 2006) is in a good agreement with Hermansen as he makes a noteworthy argument in his study on American Sufi orders that one of the most powerful power in the growing interest of American Islamic mysticism is that for many individuals, pursuing American Sufism does not require a Muslim identity.

He further elaborates: New World Islamic mysticism is practiced by Muslim and Non Muslims; it may transcend barriers of gender, generation, class and ethnicity or serve to reinforce them; it may be envisioned as inseparable from organized social interaction and expression, or imagines as a deeply private spiritual component of an individual's customized worldview. Understanding this 
borderless interaction is a crucial element in interpreting the shape and trajectory of Islamic mysticism in America. This openness, without a doubt, link back to the central tenet in Sufism i.e. mahabbah (love) - a core concept shared with many other religious teachings as well as non-theistic philosophy e.g. concept of mettā or maitrī in Buddhism or altruistic love in Christianity. From a socio-psychological perspective, Sufism also acts as a catalytic factor for resilience as a way to reconcile modernity, self-affirmation and authenticity. In this regards, quasi Sufism enables American Muslims to focus more on similarities rather than differences and presents themselves as a cosmopolitan being tied together with (religious) others through the message of peace and humanity. In this milieu, the universal-humanist face of Muslim religiosity finds a place in Western concept of humanism where positive attitude towards universal human interests and moral values predominate. Rumi's poem The Alchemy of Love perhaps best describes the essence of cosmopolitan love as an underlying principle in Sufism:

"You come to us from another world/From beyond the stars and a void of space/ Transcendent, pure - of unimaginable beauty/Bringing with You the essence of Love/ You transform all who are touched by You - Mundane concerns, troubles and sorrows dissolve in Your presence/ Bringing joy to ruler or ruled, to peasants and kings/You bewilder us with Your grace/ All evil is transformed into goodness/You are the Master Alchemist! / You light the fire of Love in earth \& sky/In heart \& soul of every being/Through Your loving, existence \& non-existence merge - All opposites unite -All that is profane becomes sacred again".

In a hopeful tone, Muqtedar Khan (2015) is optimistic with the future of American Islam as he finds uniqueness of American Sufism. Unlike traditional Sufism, which tends to revolve around long-standing mystical orders (tariqas), order specific practices, veneration of saints, and devotional music, America's emerging soft Sufism revolves around the cult of celebrity imams, huge five-star conventions, global spiritual tourism and, that is relaxing, more a knowledgeoriented approach than traditional Sufism. By and large, in the face of the second modernity, American Sufism has gone through a quite transformative phase in recent years. Once known as an ascetic spirituality, recent trend in American Sufism shows a significant shift towards a more casual perception of Sufism as a form of quick emotional fulfillment through meaningful personal rituals. The 
young observant of American Sufi, who are essentially knowledge-oriented spiritual seekers, are able to relate their quest spirituality to the plural reality of American society through a journey of self-rediscovery. Finally, as stated in the previous section, reflexivity and cosmopolitan consciousness, the two tenets making American Sufism a quasi Sufism, provides meanings for American Muslim to reconnect with his history, humanity and identity in a personal way that is contextual and meaningful at their pace. Admittedly, the future of American Islam rests on its ability to harmonize multiple forms of Islamic religiosity with the universal norms of its sacred law.

\section{Conclusion}

This paper concludes that in the wake of what has been called as the failure of political Islam worldwide, the universal-humanist face of Muslim religiosity finds a place in Western concept of humanism where positive attitude towards universal human interests predominates. From the perspective of individualization of religion in second modernity, 'individualism' allows Sufi-oriented Muslim in America to experience religious liberalism as direct connectedness to God encompasses American Muslim's individualization. It necessary to stress here that one should be able to distinguish between individualization and egoism or narcissism in the American context for the first one places God as the liberating force (from materialism and over dependency towards everything else but God) while the latter focuses on the egocentric self. While God-centric religiosity frees an individual from anxiety, egocentric religiosity cause anxiety for dependence to the self means false glorification to limitation of human capacity. It is revealed that the clientele of American Sufism, especially young Muslims, found tranquility in Sufism as it meets the need for psychological fulfillment especially during the periods of disorientation in the 19th and 20th century. Over the year, American Sufism has proven its role for a more peaceful interreligious understanding in America on account to reflexivity as and cosmopolitan consciousness. In addition to this, Sufism acts as a catalytic factor for resilience as a way to reconcile modernity, self-affirmation and authenticity for young American Muslims. This paper suggests that further research of American Sufism would consider the potential Sufism holds in enhancing civic activities, political participation and social 
engagement. Finally, I would personally endorse an interdisciplinary observation on Sufi membership among young American Muslims for future research.

\section{REFERENCES}

Adam, Barbara, U Beck, and Joost V Loon. 2005. The Risk Society and Beyond: Critical Issues for Social Theory. London: Sage Publication.

Allport, Gordon W., and J. Michael Ross. 1967. "Personal Religious Orientation and Prejudice." Journal of Personality and Social Psychology 5(4): 43243.

Batson, C. D, and W. L Ventis. 1982. The Religious Experience: A Social Psychological Perspective. New York: Oxford University Press.

Beck, Ulrich. 2010. A God on One's Own: Religion's Capacity for Peace and Potential for Violence. Cambridge: Polity Press, Malden, USA.

Beck, Ulrich, Anthony Giddens, and Scott Lash. 1994. Reflexive Modernization: Politics, Tradition and Aesthetics in the Modern Social Order. Cambridge: Polity Press.

Cesari, Jocelyne. 2009. "Islam in the West: From Immigration to Global Islam." Harvard Middle Eastern and Islamic review 8: 148-75.

Christmann, Andreas. 2008. "Reclaiming Mysticism: Anti-Orientalism and the Construction of 'Islamic Sufism' in Postcolonial Egypt." In Religion, Language, and Power, eds. Nile Green and Mary Searle-Chatterjee. London: Routledge, 57-80.

Eid, Ahmed. 2017. "UnMosqued: Why Are Young Muslim Leaving American Mosques.”

El-Menouar, Yasemin. 2014. "The Five Dimensions of Muslim Religiosity. Results of an Empirical Study." Method, Data, Analyses 8(1): 53-78.

Ferguson, R. James. 1996. "Meeting on the Road: Cosmopolitan Islamic Culture and the Politics of Sufism." The centre for East-West Cultural and Economic Studies, Research Paper (4): 1-35.

Gallagher, Stephen, and Warren Tierney. 2013. "Religiousness/Religiosity.” In Encyclopedia of Behavioral Medicine, eds. Marc D Gellman and J Rick Turner. New York, NY: Springer New York, 1653-54.

Grewal, Zareena. 2014. Islam Is a Foreign Country: American Muslim and the Global Crisis of Authority. New York: New York University Press.

Hermansen, Marcia. 1998. "In the Garden of American Sufi Movements: Hybrid 
and Perennials." In New Trends and Developments in the World of Islam, ed. P Clarke. London: Luzac Oriental, 155-78.

___ 2000. "Hybrid Identity Formation in Muslim American: The Case of American Sufi Movement." The Muslim World 90(1): 158-87.

___ . 2006. "Literary Productions of Western Sufi Movements." In Sufism in the West, eds. Jamal Malik and J Hinnells. New York: Routledge.

Khan, Muqtedar. 2015. "Future of Islam in America: A Uniquely American Sufism." http://www.patheos.com/topics/future-of-faith-in-america/ (September 29, 2018).

Malik, Jamal, and J Hinnells. 2006. Sufism in the West. New York: Routledge.

Pew Research Center. 2017. "Findings from Pew Research Center's 2017 Survey of US Muslims. Pew Research Center, Washington D.C. 26 July 2017."

Roy, Olivier. 2004. Globalized Islam: The Search for a New Ummah. New York: Columbia University Press. 